\title{
Ractopamine hydrochloride on performance and carcass traits of confined Nellores cattle
}

\author{
Cloridrato de ractopamina sobre o desempenho e características \\ de carcaça de bovinos nelores confinados
}

\begin{abstract}
João Luis Kill ${ }^{\mathrm{I}}$ Ismail Ramalho Haddade ${ }^{\mathrm{III}}$ Iron Cardoso dos Santos Júnior ${ }^{\text {IV }}$ Douglas Haese $^{\mathrm{II}}$ Alberto Chambela Neto ${ }^{\mathrm{III}}$ Pedro Veiga Rodrigues Paulinov Carolina D’ávila Possatti ${ }^{\mathrm{I}}$
\end{abstract}

\section{ABSTRACT}

The effect of four levels of inclusion (0; 450; 900 and

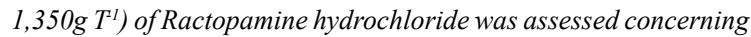
weight gain, feed conversion, dry matter intake, carcass traits and quality of castrated male cattle meat in confinement. Forty Nellore steers were used, with an average age of 26 months and initial average weight of $423.4 \pm 2.7 \mathrm{~kg}$, in a randomized block experimental design with four treatments and ten replications. The diet was fixed with the ratio of forage to concentrate dry matter of 75.3:24.7. A Linear positive effect observed was the inclusion of Ractopamine on daily weight gain and linear negative effect on feed conversion, highlighting the improvements with the increasing inclusion of Ractopamine hydrochloride. In relation to carcass traits, the linear effect was negative for fat thickness and no differences were found regarding the hot carcass weight; carcass yield; area, width and depth of rib eye area of the Longissimus dorsi muscle, and noble courts. In relation to dry matter intake, the comparison of the treatments demonstrated that Ractopamine didn't influence negatively, which highlights its positive effect on the animal performance. The use of Ractopamine improves performance and decreases de amount of superficial fat in male nellore carcass in confinement.

Key words: additive, confinement, fat thickness, tenderness.

\section{RESUMO}

Avaliou-se o efeito de quatro níveis de inclusão ( 0 ; 450; 900 e $1.350 \mathrm{~g} \mathrm{~T}^{1}$ ) do cloridrato de ractopamina, sobre o ganho de peso, a conversão alimentar, o consumo de matéria seca, as características de carcaça e a qualidade de carne de bovinos machos castrados em confinamento. Foram utilizados 40 bovinos da raça Nelore, com idade média de 26 meses e peso médio inicial de 423,4 2,7kg, em um delineamento experimental em blocos casualizados, com quatro tratamentos e dez repetições. A dieta foi fixada obedecendo-se razão volumoso:concentrado de 75,3:24,7 na matéria seca. Observou-se efeito linear positivo da inclusão da ractopamina sobre o ganho de peso diário e efeito linear negativo sobre a conversão alimentar, com destaque para as melhorias com o aumento da inclusão do cloridrato de ractopamina. Em relação às características de carcaça, observou-se o efeito linear negativo para a espessura de gordura e não foram observadas diferenças quanto ao peso da carcaça quente; rendimento de carcaça; área, largura e profundidade de área de olho de lombo do músculo Longissimus dorsi, e cortes nobres. Em relação ao consumo de matéria seca, a comparação dos tratamentos demonstrou que a ractopamina não influencia negativamente no consumo, o que evidencia seu efeito positivo no desempenho animal. $O$ uso do cloridrato de ractopamina melhora o desempenho e diminui a quantidade de gordura superficial na carcaça de bovinos machos nelore em confinamento.

Palavras-chave: aditivo, confinamento, espessura de gordura, maciez.

\section{INTRODUCTION}

Currently, one of the interests in beef cattle nutrition directs the investigations into food additives for the use in feedlots, in order to improve animal performance and financial efficiency with the exploration of these systems. In confinement, one of the additives used was ractopamine hydrochloride, which must be supplied in the last 42 days of the termination, increasing weight gain, improving feed

\footnotetext{
${ }^{\text {I} C e n t r o ~ d e ~ T e c n o l o g i a ~ A n i m a l ~ L t d a . ~(C T A), ~ D o m i n g o s ~ M a r t i n s, ~ E S, ~ B r a s i l . ~}$

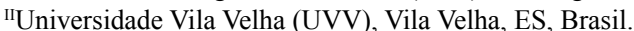

IIIInstituto Federal de Educação, Ciência e Tecnologia do Espírito Santo (IFES), Santa Teresa, ES, Brasil.

${ }^{\text {IV}}$ Programa de Mestrado em Ciência Animal, UVV, 29102-606, Vila Velha, ES, Brasil. E-mail: ironcardoso@yahoo.com.br.

Corresponding author.

${ }^{v}$ Cargill/Nutron, Nutron Alimentos Ltda, Campinas, SP, Brasil. 
efficiency and increase muscle deposition in the tissue (QUINN et al., 2008). Several studies have demonstrated that this additive provides effect on carcass characteristics and meat quality (SCRAMLIN et al., 2009). In addition, the ractopamine hydrochloride is considered a beta blocker, that is, an organic molecule that links to receptors, present in most mammalian cells, promoting further development of muscle mass through hypertrophy and lower fat deposition (DUNSHEA et al., 2005).

The objective in this research was to evaluate the effect of ractopamine hydrochloride, in four levels of inclusion $\left(0 ; 450 ; 900\right.$ and $\left.1,350 \mathrm{~g} \mathrm{~T}^{-1}\right)$ in nellore castrated cattle confined for 42 days, in terms of weight gain, feed conversion, dry matter intake and carcass traits.

\section{MATERIAL AND METHODS}

The experiment was accomplished in the Cattle sector of the Federal Institute of Education, Science and Technology of Espírito Santo, Santa Teresa Campus, in 42 days, from March to May 2012. The animals were kept in an open solitary confinement, in an experimental area consisting of four sub-areas of 0.5 ha each, fitted with troughs and feeders with 10 meters of a concrete floor, in addition to a corral for the centralized containment, weighing and handling of animals. Forty Nellore castrated male steers were used, with an average age of 26 months \pm 4 months and initial average weight of $423.4 \pm 2.7 \mathrm{~kg}$. The experiment design used was randomized complete blocks with four treatments and ten replications. The animals had undergone a prior period of 20 days, for adaptation to premises and to the diet, and the full trial period was 42 days.

The animals were subjected to a diet composed of corn silage $(75.3 \%)$ and concentrated (24.7\%) provided ad libitum, twice a day throughout the experimental period. The concentrate was formulated based on ground corn $(11.1 \%)$, soybean meal $(9.3 \%)$, urea livestock $(0.4 \%)$ and mineral salt $(3.9 \%)$, on dry matter basis. The food formulation and the amount provided to animals a day were quantified to gain live weight of $1.2 \mathrm{~kg} \mathrm{day}^{-1}$ (NRC, 2000), once the different treatments are characterized only by the inclusion of the feed additive ractopamine hydrochloride in quantities of 0 (T1), 450 (T2), 900 (T3) and 1,350 (T4) $\mathrm{g} \mathrm{T}^{-1}$. The quantities provided daily and the leftovers of the total feed were observed and recorded daily, allowing determining the average dry matter intake in each treatment. The animals were weighed after 12 hours of fasting, to determine the daily average live weight gain. The efficiency of feed transformation into weight gain was evaluated by means of the feed conversion ratio based on dietary dry matter (CAMS, kg DM/kg gain).

For the estimation of fecal dry matter, it was utilized the external indicator LIPE ${ }^{\circledR}$, based on lignin molecule (SALIBA et al. 2003). The LIPE ${ }^{\circledR}$ was administered in two animals of each treatment, through the probe, in daily dosage of $500 \mathrm{mg}$ animal ${ }^{-1}$, provided in the morning, once a day for seven consecutive days, being two days of adaptation and five days of rectal feces collection. Subsequently, the fecal samples were dried in ventilated greenhouse to $55 \pm 5^{\circ} \mathrm{C}$, milled, homogenized, constituting a composed sample for each animal. Then were placed in plastic jars with lids and forwarded for analysis, in the laboratory of Animal nutrition at UFMG. For the determination of fecal production $\left(\mathrm{kg} \mathrm{day}^{-1}\right.$ of $\left.\mathrm{DM}\right)$ of each animal, the following equation was utilized: $\mathrm{FP}(\mathrm{kg})=($ Amount administered/LIPE concentration in feces) $\mathrm{x} 100$. In vitro digestibility of silage used in the experiment was obtained to the forage dry matter intake. So, with the values of fecal production (FP) and in vitro digestibility it was estimated dry matter of forage intake (DMI) by means of the equation:

DMI $=$ FP/(1-IVDMD/100), where:- DMI = Dry Matter Intake; FP = fecal Production; IVDMD = In Vitro Dry Matter Digestibility. In addition to the determinations of forage intake, the average daily intake of concentrated and forage feed were recorded for the difference between the quantity supplied and leftovers, this added to record the total dry matter intake per animal per day.

In the end of the study, eight animals in each treatment were slaughtered after 12 hours of fasting. The carcasses were cut by the sternum and the spine, resulting in two halves, which were weighted, determining the weight of hot carcass $(\mathrm{HCW})$, which allowed to calculate the hot carcass yield (WHR).

Later, the right half-carcasses were identified and placed in cold Chamber, maintained at $1^{\circ} \mathrm{C}$, in which remained during 24 hours. After this period, it was separated in the following primary cuts, cushion, need lenose, termite, full Chuck and rump to the determination of the yield of each cut. In a 
cross-section between the $12^{\text {th }}$ and $13^{\text {th }}$ ribs, is found the Longissimus dorsi muscle (LD), which was held to measure the thickness of fat obtained in the third quarter of the height of the muscle from the spine, with the aid of a caliper. It also assesses the loin eye area of each animal, by means of overlay the perimeter of the muscle, in parchment paper, which then was bounded by planimetry with the use of the software AutoCAD R14. It was also proceeded to assess the length and depth of the LD muscle according to the methodology described by FARROW et al. (2009).

The datas were subjected to analysis of variance and regression, considering 5\% for the alpha error. The analyses were performed by using the statistical program SAEG 9.1 (UFV, 2007).

\section{RESULTS AND DISCUSSION}

The performance results of cattle in termination phase supplemented with different levels of Ractopamine hydrochloride inclusion can be found in table 1. Increasing linear effect was observed $(\mathrm{P}<0.05)$ on daily weight gain of animals with increasing addition of the additive (Figure 1). Thus, the animals that received ractopamine in the diet at levels of $450 \mathrm{~g} \mathrm{~T}^{-1}$ (9ppm), $900 \mathrm{~g} \mathrm{~T}^{-1}(18 \mathrm{ppm})$ and $1,350 \mathrm{~g}$ $\mathrm{T}^{-1}(27 \mathrm{ppm})$ showed, respectively, increases of 9.05 ; 13.49 and $14.05 \%$ in weight gain compared to those who did not receive this additive. Similar results were observed by QUINN et al. (2008), when fed cattle in termination diets containing $9.1 ; 18.2$ and $27.3 \mathrm{ppm}$ of ractopamine hydrochloride, with increases in weight gain in $17.1,19.6$, and $25.7 \%$, respectively, compared to bovine animals not supplemented with this beta blocker. These results presented here were also corroborated by those obtained by ABNEY et al. (2007) with improvement in weight gain of cattle fed diets supplemented with Ractopamine. The increase in cattle weight gain probably has occurred due to the effect of this additive on the modification of cellular metabolism, which would promote increased protein synthesis and decreased lipogenesis.

The food conversion improved linearly $(\mathrm{P}<0.05)$ with the increased level of Ractopamine (LR) in the diet (Table 1 and Figure 1). This result is in agreement with those obtained by ABNEY

Table 1 - Performance results and carcass characteristics of Nellore cattle supplemented with different levels of ractopamine hydrochloride.

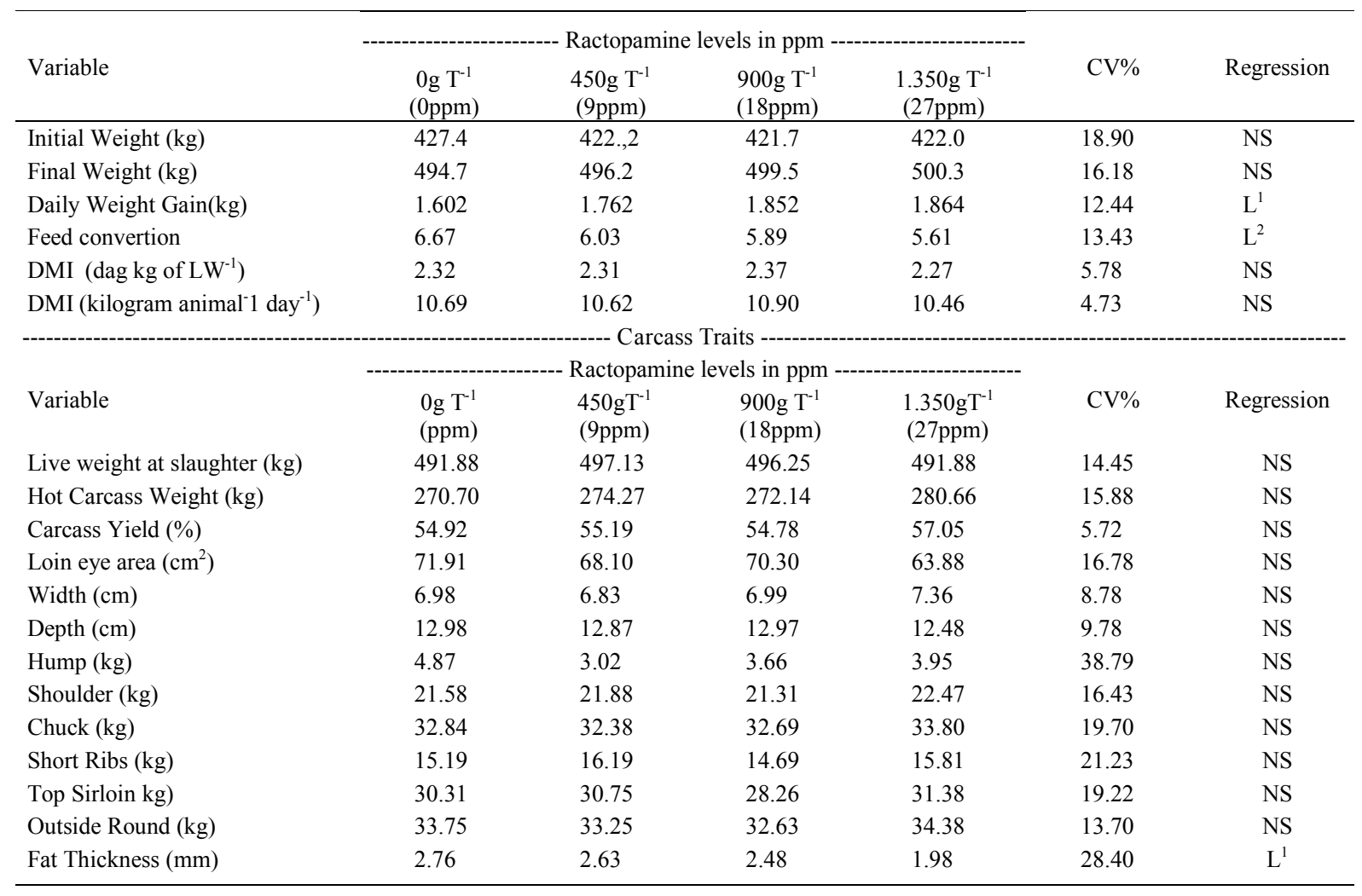

${ }^{1}$ Linear Increasing Effect $(\mathrm{P}<0.05) ;{ }^{2}$ Linear decreasing Effect $(\mathrm{P}<0.05)$ and ${ }^{3} \mathrm{NS}-$ not significant $(\mathrm{P}>0.05)$.

Ciência Rural, v.45, n.10, out, 2015. 


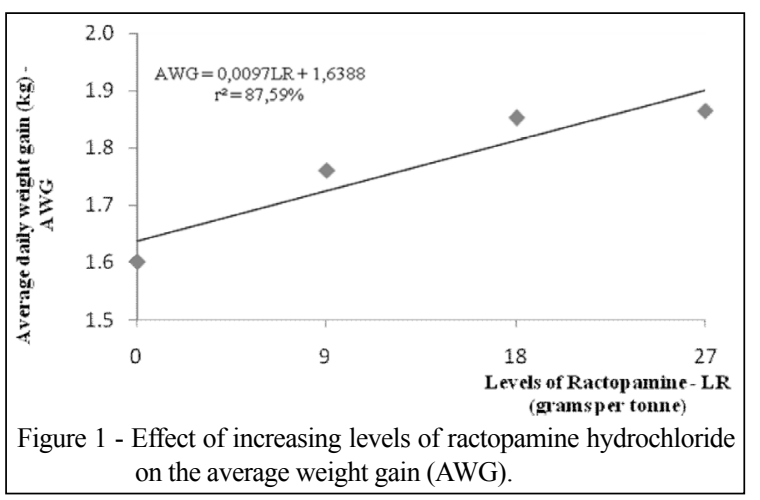

et al. (2007) and QUINN et al. (2008). The best feed conversions under effect of ractopamine hydrochloride, must have occurred in relation to the possible targeting of nutrients to muscle deposition in the tissue, modulated by this additive. This occurred because lean tissue synthesis requires less nutrients than the synthesis of fat. In addition the deposition of muscle tissue demand less energy supply, being three times less compared to that required for the deposition of adipose tissue.

The results of hot carcass weight (HCW), carcass yield (CY), noble cuts weight, loin eye area (LEA), width, depth and thickness of the Longissimus dorsi muscle fat (LD) are shown in table 1. There was no effect $(\mathrm{P}>0.05)$ levels of Ractopamine on $\mathrm{HCW}$ variables, CY, LEA, noble cuts weight and width and depth of the LD muscle. Similar results were obtained by GRUBER et al. (2007) and QUINN et al. (2008) for CY and LEA, respectively. However, differ from other studies that showed increase in CY, and on LEA, cattle fed ractopamine QUINN et al. (2008).

The decrease in the thickness of subcutaneous fat was significant $(\mathrm{P}<0.05)$ with the increased levels of Ractopamine added in the diet, and it occurred linearly (Figure 2). In fact ractopamine

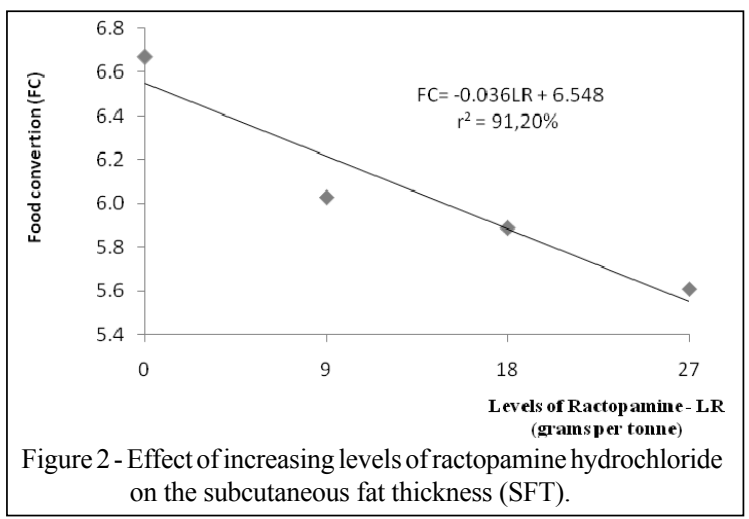

has a peculiar effect on the modification and finishing carcass. SCRAMLIN et al. (2009), noted its significant effect in reducing the thickness of fat, the same occurring for other authors (WINTERHOLLER et al., 2008), which found the same behavior for this variable.

The averages, with their respective standard deviations, to fecal production (FP), in $\mathrm{kg}$ of dry matter, obtained from external indicator named $\mathrm{LIPE}^{\circledR}$, and dry matter intake (DMI), through in vitro dry matter digestibility (IVDMD), as a percentage, are shown in table 1 .

The external indicator LIPE $^{\circledR}$ has been successfully used to estimate fecal production, being one of the tools that makes easier to evaluate dry matter forage intake by ruminants, especially when considering the difficulties to determine it, in animals under grazing SALIBA et al. (2003), or when is necessary to estimate the individual feed intake of animals kept in collective bays. So in this experiment, the dry matter fecal production (DMFP) and the dry matter intake of the total ration were not different $(\mathrm{P}>0.05)$ among treatments (Table 1). This fact shows the positive effect of ractopamine inclusion in the diet of animals, which showed higher daily weight gain and better feed conversion in cattle that received the additive Ractopamine (Figure 3). Asimilar result was found by WALKER et al. (2006), where the DMI was not affected by the inclusion of Ractopamine. In the experiment conducted by QUINN et al. (2008), the DMI datas were also not different $(\mathrm{P}>0.05)$ between the animals and the controls who received ractopamine. However, in some studies as the one conducted by AVENDANOREYES et al. (2006), cattle supplemented with Ractomamine consumed significantly $(\mathrm{P}<0.01)$ less dry matter $\left(8,4 \mathrm{~kg} \mathrm{day}^{-1}\right)$ than control animals $(8,5 \mathrm{~kg}$ day $\left.{ }^{-1}\right)$, which can enhance the positive effect of this additive used for cattle on termination.

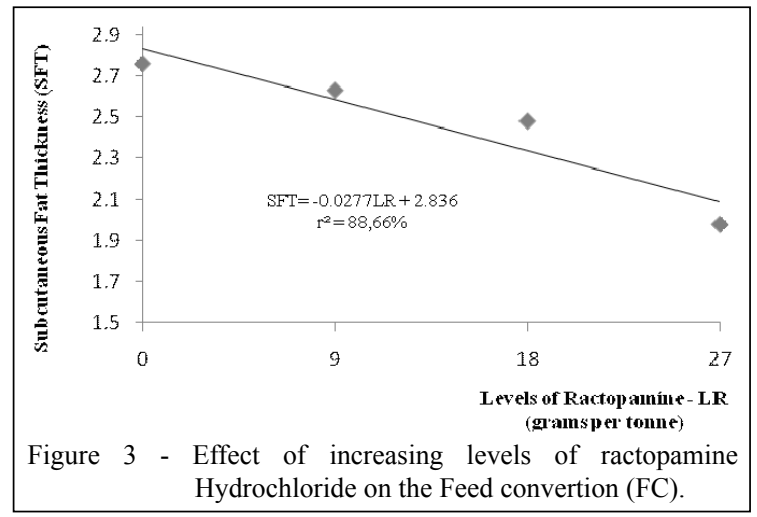

Ciência Rural, v.45, n.10, out, 2015. 


\section{CONCLUSION}

The inclusion of ractopamine Hydrochloride for nellore cattle castrated males at termination phase, increases weight gain, improves feed conversion, and has no influence on dry matter intake. In addition, it reduces the thickness of superficial fat on the carcass.

\section{ACKNOWLEDGEMENTS}

The authors appreciate the Instituto Federal do Espírito Santo (IFES), Santa Teresa Campus, Universidade de Vila Velha (UVV), Universidade Fedral de Viçosa (UFV), Centro de Tecnologia Animal Ltda (CTA), Quimiplan Consultoria Ltda and Nutriave Foods Ltda. by enabling the realization of this study.

\section{ETHICS AND BIOSAFETY COMMITTEE}

The authors emphasize that the animals were kept in good conditions and there was no action that would cause discomfort to them and assume the responsibility for any future questioning about the experiment.

\section{REFERENCES}

AVENDANO-REYES, L. et al. Effects of two beta-adrenergic agonists on finishing performance carcass characteristics, and meat quality of feedlot steers. Journal of Animal Science. v.84, n.12, p.3259-3265, 2006. Available from: <http://www. journalofanimalscience.org/content/84/12/3259.long>. Accessed: Jan. 24, 2013. doi: 10.2527/jan.2006-173

ABNEY, C.S. et al. Effects of ractopamine hydrochloride on performance, rate and variation of intake, and acid-base balance in feedlot cattle. Journal of Animal Science, v.85, n.11, p.3090 3098, 2007. Available from: $<$ http://www.journalofanimalscience. org/content/85/11/3090.long >. Accessed: Jan. 24, 2013. doi: $10.2527 /$ jas.2007-0263

DUNSHEA, F.R. et al. Effects of dietary factorsand other metabolic modifiers on quality and nutritional value of meat. Meat Science, v.71, p.8-38, 2005. Available from: <http://www.meatfood.com/ allfile/techpaper/2005/Effects $\% 20$ of $\% 20$ dietary $\% 20$ factors $\% 20$ and $\% 20$ other $\% 20$ metabolic $\% 20$ modifiers $\% 20$ on $\% 20$ quality $\% 20$ and $\% 20$ nutritional $\% 20$ value $\% 20$ of $\% 20$ meat.pdf $>$. Accessed: May 27, 2013. doi: 10.1016/j.meatsci.2005.05.001
FARROW, R.L. et al. An exploratory observational study to develop an improved method for quantifying beef carcass salable meat yield. Meat Science, v.82, n.12, p.143-150, 2009. Available from: <http://www.sciencedirect.com/science/article/ pii/S0309174009000047?np=y>. Accessed: May 24, 2013. doi: 10.1016/j.meatsci.2008.12.014.

GRUBER, S.L. et al. Effects of ractopamine supplementation on growth performance and carcass characteristics of feedlot steers differing in biological type. Journal of Food Science, v.85, n.7, p.1809-1815, 2007. Available from: <http://www. journalofanimalscience.org/content/85/7/1809.short $>$. Accessed: Mar. 22, 2013. doi: 10.2527/jas.2006-634.

NATIONAL RESEARCH COUNCIL (NRC). Nutrient requirements of beef cattle. Washington, D.C.: National Academy, 2000. p.261.

QUINN. M.J. et al. The effects of ractopamine-hydrogen chloride (Optaflexx) on performance, carcass characteristics, and meat quality of finishing feedlot heifers. Journal of Animal Science, v.86, n.4 p.902-908, 2008. Available from: $<$ http://www. journalofanimalscience.org/content/86/4/902.long $>$. Accessed: Apr. 4, 2013. doi: 10.2527/jas.2007-0117.

SALIBA, E.O.S. et al. Purified lignin extraded from Eucalyptus grandis (PELI), E. used as an external marker in digestibility trials in various animal species. In: WORD CONFERENCE ON ANIMAL PRODUCTION, 9., 2003, Porto Alegre, RS. Proceedings... Porto Alegre: WAAP/ALPA/SBZ/UFRGS, (CDROM) p. 1-3, 2003.

SCRAMLIN, S.M. et al. Comparative effects of ractopamine hydrochloride and zilpaterol hydrochloride on growth performance, carcass traits, and longissimus tenderness of finishing steers 1. Journal of Animal Science, v.88, n.5, p.1823-182, 2009. Available from: <http://www.journalofanimalscience.org/content/88/5/1823. long>. Accessed: Jan. 21, 2013. doi: 10.2527/jas.2009-2405.

UNIVERSIDADE FEDERALDE VIÇOSA(UFV). S.A.E.G. (Sistemas de análises estatísticas e genéticas). Viçosa, 2007. Versão 9.1.

WALKER, D.K. et al. Effects of ractopamine and protein source on growth performance and carcass characteristics of feedlot heifers. Journal of Animal Science, v.84, n.10, p.2795-2800, 2006. Available from: <http://www.journalofanimalscience.org/ cgi/pmidlookup?view=long\&pmid $=16971581>$. Accessed: Jan. 3, 2013. doi: 10.2527/jas.2005-614.

WINTERHOLLER, S.J. et al. Effect of the management system in response to the containment ractopamine- $\mathrm{HCl}$ yearling steers. Journal of Animal Science, v.86, p.2401-2414, 2008. 